\title{
Correlations among Yield, Taste, Tuber Characteristics and Mineral Contents of Potato Cultivars Grown at Different Growing Conditions
}

\author{
Bogdan Flis ${ }^{1}$, Ewa Zimnoch-Guzowska ${ }^{1} \&$ Dariusz Mańkowski ${ }^{2}$ \\ ${ }^{1}$ Plant Breeding and Acclimatization Institute, National Research Institute, Młochów Research Centre, Młochów, \\ Platanowa 19 str., 05-831 Młochów, Poland \\ ${ }^{2}$ Plant Breeding and Acclimatization Institute, National Research Institute, Radzików, 05-870 Błonie, Poland \\ Correspondence: Bogdan Flis, Plant Breeding and Acclimatization Institute, National Research Institute, \\ Młochów Research Centre, Młochów, Platanowa 19 str., 05-831 Młochów, Poland. Tel: 48-22-729-9248. E-mail: \\ b.flis@ihar.edu.pl
}

Received: March 14, 2012 Accepted: March 28, 2012 Online Published: June 6, 2012

doi:10.5539/jas.v4n7p197 URL: http://dx.doi.org/10.5539/jas.v4n7p197

This work was supported by EU project SAFE FOODS and $R+D$ Project "Identification of genetic sources of table potato useful for ecological and low input cultivation systems" funded by Polish Ministry of Agriculture and Rural Development.

\begin{abstract}
To test expected positive impact of organic cultivation on potato tubers quality and their mineral composition, selected potato cultivars were planted in conditions of two conventional and two organic farms in central and northern Poland in 2006. Lower tuber yield and elevated levels of quality traits (including tuber flavor) were characteristics of organic locations. Cultivar by location interaction significantly affected tuber flavor. The mineral composition of tubers reflects local variation in this respect, since in organically grown tubers only $\mathrm{P}$ and $\mathrm{Cu}$ reached higher, while $\mathrm{Mn}$ and $\mathrm{Cd}$ had lower tuber concentrations. The tuber concentration of these elements strongly correlated with the tuber yield (respectively negatively and positively). For other mineral elements and quality traits correlations were rare, mostly moderate and negative. Generally, potato cultivar should be adapted to the specific growing conditions to achieve improvement of quality traits. An observed cultivar effect indicates possibility of applying breeding methods for developing cultivars with desired mineral composition of tubers.
\end{abstract}

Keywords: quality traits, tuber flavor, mineral elements, cultivation systems, potato cultivars

\section{Introduction}

Production indices show that potato (Solanum tuberosum L.) is one of the major crops in the world (http://faostat.fao.org). It is valuable source of energy and compounds important in human diet. Potato tubers supply mainly carbohydrates, but are also relatively rich source of proteins, vitamins, dietary fibre and some minerals. Among the latter, $\mathrm{K}$ is the most important element. Phosphorus has the second and $\mathrm{Mg}$ the third highest level in tubers. Trace element levels are much lower, but potato tubers may substantially contribute in providing $\mathrm{Fe}$ and $\mathrm{Zn}$ to the diet (see eg. refs. Lisińska \& Leszczyński, 1989; Kärenlampi \& White, 2009). However, these valuable traits will not attract consumers, unless potato tubers have a good flavor.

The flavor of tubers depends on volatile and non-volatile compounds as well as on texture of potatoes (boiled or baked). Flavor of food is among the most important factors for consumers and yet one of the most difficult aims for breeding programs. Generally, improvement of potato tubers' flavor by breeding methods is difficult and time-consuming, because of a very complex chemistry, changes of compounds during boiling, unknown underlying genetics and environmental factors during growth and storage (Jansky, 2010).

Today, growing organic food is commonly accepted alternative way of improving dietary value and/or flavor. Purchasers of such food assume that organic farming practice positively affects products, which is more nutritious and tasty than conventional food. The opposite beliefs are among reasons for not purchasing organically grown foods. These contrasting attitudes are reflected by divergent empirical evidence on the role of taste in consumer decision. Such conflicting conclusions may be also drawn from comparisons between conventionally and organically grown foods in respect of concentration of specific nutrients (compounds and/or 
elements) (see e.g. refs. Bourn \& Prescott, 2002; Lairon, 2009; Magkos et al., 2006).

Mineral composition of tubers was widely investigated. White et al. (2009) summarized these researches and concluded that mineral concentrations depend on the phytoavailability of different elements to the potato crop (what is additionally indicated by the marked location influence on these concentrations) and on potato genotype. Relatively few publications are devoted to comparisons of mineral compositions of tubers from organic and conventional cultivations. In organically grown tubers, the concentrations of some elements are higher (for iron and macronutrients with exception of $\mathrm{N}$ ) or lower (for $\mathrm{N}$ and $\mathrm{Mn}$ ) as compared to tubers from conventional cultivation (Schupan, 1974; Warman \& Havard, 1998; Wszelaki et al., 2005).

As for the other agronomic and quality characteristics of potato, comparisons between organically and conventionally cultivated potatoes are poorly represented in the literature. As compared to conventional cultivation, organically grown potatoes give lowered yield (Varis et al., 1996; Hajšlova et al., 2005; Maggio et al., 2008), higher dry matter content of tubers (Rembiałkowska, 2003; Hajšlova et al., 2005; Kolbe et al., 1995) and tubers, which are usually more tasty (Rembiałkowska, 2003; Wszelaki et al. 2005; Varis et al., 1996). However, it should be emphasized that other authors found no such differences in tuber yield (e.g. Warman \& Havard, 1998), dry matter content (Maggio et al., 2008) or in tubers flavor (Hajšlova et al., 2005).

The aim of the present study was to evaluate the response of selected potato cultivars to conventional and organic cultivation in terms of flavor and other agronomic and quality traits as well as mineral composition of tubers. The basic assumption was to obtain data from field experiments performed in conditions of real organic and conventional production to get the information whether cultivation system give rise of differences, which are important for farmer (like tuber yield and its quality) and consumer (tuber quality). Furthermore, whether these differences are related to mineral composition of tubers.

\section{Material and Methods}

\subsection{Plant Material}

For field experiments, 11 Polish (Bartek, Beata, Bryza, Danusia, Maryna, Mors, Tokaj, Triada, Wiking, Zebra, Zeus) and three Dutch (Asterix, Redstar, Victoria) table potato cultivars were selected, which are commonly grown in Poland. Their descriptions can be found in the Descriptive List of Agricultural Plant Varieties of Polish Research Center for Cultivar Testing (Kamasa \& Lenartowicz, 2005).

\subsection{Field Experiments and Testing of Tuber Traits}

The field experiments were performed at four locations using the above-mentioned 14 potato cultivars. At two locations in northern Poland O1 (Godki near Olsztyn) and O2 (near Nowe Miasto Lubawskie), the organic system was applied. Wheat (in O1) or spelt wheat (in O2) were forecrops. Before planting composted cattle manure was added to the soil in a rate of $30 \mathrm{tha}^{-1}$. During vegetation stage approved pesticides were applied, i.e. copper fungicides against late blight and pyrethrin (plant extract) or Novodor against Colorado beetle. Polish company AGRO BIO TEST certified both organic farms. The company implemented a quality system in 2002 according to the norm EN 45011 and received accreditation from the Polish Centre of Accreditation (AC 096). Both locations were organically treated for at least five years.

At locations C1 (Młochów in central Poland) and C2 (Zamarte in northern Poland) potatoes were grown under conventional cultivation systems. Forecrop was sugar beet (in $\mathrm{C} 1$ ) or wheat (in $\mathrm{C} 2$ ). Fertilizers doses were as follows: (a): $93 \mathrm{~kg} \mathrm{~N} \mathrm{ha}^{-1}, 91 \mathrm{~kg} \mathrm{P}_{2} \mathrm{O}_{5} \mathrm{ha}^{-1}$ and $170 \mathrm{~kg} \mathrm{~K}_{2} \mathrm{O} \mathrm{ha}^{-1}$ at location C1; (b): $92 \mathrm{~kg} \mathrm{~N} \mathrm{ha}^{-1}, 75 \mathrm{~kg} \mathrm{P}_{2} \mathrm{O}_{5}$ $\mathrm{ha}^{-1}$ and $190 \mathrm{~kg} \mathrm{~K}_{2} \mathrm{O} \mathrm{ha}{ }^{-1}$ at the second location C2. Additionally, during vegetation stage foliar application of some fertilizers was used, i.e. urea $\left(10 \mathrm{~kg} \mathrm{~N} \mathrm{ha}^{-1}\right)$ in $\mathrm{C} 1$ and $\mathrm{Mg}$ sulphate $\left(1 \mathrm{~kg} \mathrm{MgSO}_{4} \mathrm{ha}^{-1}\right)$ at $\mathrm{C} 2$. Full chemical protection of plants was applied at both conventional locations.

At locations $\mathrm{O} 1$ and $\mathrm{C} 1$ (both located in northern part of Poland), trials were performed on plots on loamy soil. In locations O2 (northern Poland) and C2 (central Poland) trials were placed on sandy clay soil. The fields were not irrigated. For field experiments, Randomized Complete Block design was applied: three blocks (or replications) with 15 hill (plants) plots at each.

The planting was executed during 25-30 April, and conventionally grown seed tubers were used. After harvest (16 weeks after planting), evaluations of tubers were done and these included assessment of total and marketable tuber yield (fraction of yield of tubers with diameter $>4 \mathrm{~cm}$ ), percentage of starch content (according to procedure of Zgórska, 2001) and morphology of tubers (assessed in 1-9 scale for regularity of tuber shape and depth of eyes or in 1-5 scale for tuber shape accordingly to Domański 2001). Tubers were kept in standard storage for two months and subsequently tuber flavor was assessed in 1-9 scale. The assessments of flavor were done according to procedure described by Domański (2001a) with exception of tuber texture characteristic. The 
testing team consisted of six persons experienced in flavor evaluation. To avoid evaluation bias, all tuber samples were coded and randomized before testing.

\subsection{Mineral Analysis}

Potato tuber flesh samples from 5-6 tubers collected from each location and replication were freeze dried (Labconco FreeZone ${ }^{\circledR}$ ). Freeze-dried samples were prepared eight weeks after harvest and submitted to the Regional Station for Agricultural Chemistry Warsaw, Wesoła for the analysis of content of nine mineral elements and three heavy metals by:

- $\quad$ titrimetric method (for nitrogen $-\mathrm{N}$ ),

- $\quad$ colorimetric method (for phosphorus - P),

- $\quad$ flame photometry (for potassium and calcium - K and $\mathrm{Ca}$ ),

- $\quad$ atomic absorption spectrometry for magnesium, zinc, iron, manganese, copper ( $\mathrm{Mg}, \mathrm{Zn}, \mathrm{Fe}, \mathrm{Mn}, \mathrm{Cu})$ and heavy metals cadmium, lead and mercury $(\mathrm{Cd}, \mathrm{Pb}$ and $\mathrm{Hg})$.

Similar methods were applied for soil samples, which were collected before applying fertilizers or composted manure. Samples were collected according to the Polish Standard PN-R-04031:1997: (a) samples were taken from the soil layers with a maximum depth of $20 \mathrm{~cm}$, (b) from each field 20 initial soil samples were taken, then mixed to form $0.5 \mathrm{~kg}$ final sample.

\subsection{Data Analysis}

Flavor of boiled tubers and other traits of cultivars (in terms of tuber yield, morphology and starch content) were subjected to the analysis of variance. For mineral concentrations in tubers grown at four locations, the analysis of covariance was applied. In this analysis, the covariate was the soil level of relevant element (or soil $\mathrm{pH}$ in the case of tuber $\mathrm{Ca}$ concentration). For multiple comparisons of mean values, the Tukey's HSD test was used.

For evaluation of relationships between concentration of minerals in tubers and agronomic traits or mineral content of soil, Pearson's correlation coefficients ( $r$ ) were calculated. Further, statistically significant values of $r$ in the range $0.1 \leq \mathrm{r}<0.3$ are described as "poor correlation", $0.3 \leq \mathrm{r}<0.5$ as "moderate correlation", $0.5 \leq \mathrm{r}<0.7$ as "high correlation" and values in the range $0.7 \leq \mathrm{r}<0.9$ - as "very high".

For all traits of tubers (agronomic and concentrations of mineral elements) correlation matrix was calculated and used in principal components analysis (PCA). Components were extracted from the data and loadings of components were analyzed.

To perform those analyses, procedures of Statistical Analysis System version 9.2 (SAS Institute, Cary, NC, USA) were applied.

\section{Results}

\subsection{General Performance of Cultivars and Tuber Flavor}

The performance of all cultivars was tested in respect of tuber yield, their morphology and flavor. Values of all eight traits were significantly influenced by the effect of cultivar and location (at $P \leq 0.01$ ). The values of tuber size, starch content, tuber morphology and flavor of tubers were significantly affected by the interaction between cultivar and location $(P \leq 0.01)$, in contrast to marketable $(P \leq 0.05)$ and total tuber yield (interaction had an insignificant effect) (not shown in table). The mean values of traits evaluated at each location are presented in Table 1. The highest total and marketable tuber yield and largest tubers were found at the conventional location $\mathrm{C} 2$. The lowest yield was observed at the organic location $\mathrm{O} 2$, which was more than twice lower than at location $\mathrm{C} 2$. The starch content was less variable and organic and conventional locations could not be separated in this respect. Morphology of tubers (i.e. regularity of tubers' shape and depth of eyes) from organic locations was significantly better than that observed at conventional locations. Interestingly, the location of experiment affected the evaluations of tuber shape (Table 1).

The flavor was significantly influenced by the system of cultivation, since the scores for tubers from organic locations were significantly higher in comparison with scores from conventionally grown tubers (6.5 and $6.3 \mathrm{vs.}$ 5.6 and $5.6-$ Table 1). However, these scores were also influenced by cultivar $\times$ location interaction, which is illustrated by grouping of cultivars according to flavor's scores in Table 2. Three cultivars grown in organic locations obtained scores lower than five, as compared with eight cultivars conventionally grown. The group of very good flavor had four cultivars cultivated organically and only one cultivar from conventionally cultivated field. The accordance of evaluations was only slightly better for tubers from organic locations, since seven cultivars from organic and five from conventional cultivation were placed in the same class of flavor. 
Nevertheless, there was a group of cultivars, which reacted positively for organic cultivation (i.e. the scores from both organic locations were higher than those from conventional ones), namely cvs. Bryza, Zebra, Victoria, Triada and also cvs. Danusia, Redstar, Tokaj. Some cultivars had only one positively outstanding assessment for tubers from organic (as cvs. Wiking, Zeus, Maryna) or conventional locations (cvs. Beata or Asterix) - Table 2.

Table 1. Mean values of agricultural traits measured in organic $(\mathrm{O} 1, \mathrm{O} 2)$ and conventional $(\mathrm{C} 1, \mathrm{C} 2)$ locations

\begin{tabular}{|c|c|c|c|c|c|c|c|c|}
\hline Location & $\begin{array}{l}\text { Total tuber } \\
\text { yield kg } \\
\text { plot }^{-1}\end{array}$ & $\begin{array}{l}\text { Fraction of } \\
\text { marketable tuber } \\
\text { yield }\end{array}$ & $\begin{array}{l}\text { Tuber } \\
\text { size }^{\text {a }}\end{array}$ & $\begin{array}{l}\% \text { of starch } \\
\text { content }\end{array}$ & $\begin{array}{l}\text { Tuber } \\
\text { shape }^{b}\end{array}$ & $\begin{array}{l}\text { Regularity of } \\
\text { tuber shape }\end{array}$ & $\begin{array}{l}\text { Depth of } \\
\text { eyes }^{\text {a }}\end{array}$ & $\begin{array}{l}\text { Flavor } \\
\text { a }\end{array}$ \\
\hline O1 & $11.04 \mathrm{c}$ & $0.84 \mathrm{c}$ & $5.0 \mathrm{~b}$ & $15.1 \mathrm{~b}$ & $3.5 \mathrm{a}$ & $7.0 \mathrm{~b}$ & $7.1 \mathrm{~b}$ & $6.5 \mathrm{a}$ \\
\hline $\mathrm{O} 2$ & $9.05 \mathrm{~d}$ & $0.86 \mathrm{c}$ & $4.5 \mathrm{c}$ & $15.4 \mathrm{a}$ & $3.3 \mathrm{c}$ & $7.6 \mathrm{a}$ & $7.5 \mathrm{a}$ & $6.4 \mathrm{a}$ \\
\hline $\mathrm{C} 1$ & $18.51 \mathrm{~b}$ & $0.89 \mathrm{~b}$ & $4.9 \mathrm{~b}$ & $16.2 \mathrm{a}$ & $2.7 \mathrm{~d}$ & $6.5 \mathrm{~d}$ & $6.7 \mathrm{~d}$ & $5.6 \mathrm{~b}$ \\
\hline $\mathrm{C} 2$ & $21.66 \mathrm{a}$ & $0.94 \mathrm{a}$ & $6.2 \mathrm{a}$ & $14.7 \mathrm{~b}$ & $3.4 \mathrm{~b}$ & $6.7 \mathrm{c}$ & $7.0 \mathrm{c}$ & $5.6 \mathrm{~b}$ \\
\hline
\end{tabular}

a-scale $1-9$, where 9 is the largest or the best or the shallowest or very tasty.

${ }^{b}$ - scale $1-5$, where 1 is round and 5 is the long tuber.

Mean values followed by the same letter for each column do not differ significantly at $P \leq 0.05$.

Table 2. Cultivars grouping according to location and flavour classes

\begin{tabular}{|c|c|c|c|c|}
\hline \multirow{2}{*}{$\begin{array}{l}\text { Class of } \\
\text { flavour }\end{array}$} & \multicolumn{4}{|c|}{ Cultivars in location } \\
\hline & $\mathrm{O} 1$ & $\mathrm{O} 2$ & $\mathrm{C} 1$ & $\mathrm{C} 2$ \\
\hline $\begin{array}{l}\text { very good, } \\
>7\end{array}$ & $\begin{array}{l}\text { Bryza, Victoria, } \\
\text { Wiking, Zebra }\end{array}$ & Bryza & & Beata \\
\hline $\begin{array}{l}\text { good, }>6- \\
7\end{array}$ & $\begin{array}{l}\text { Bartek, Danusia, } \\
\text { Triada }\end{array}$ & $\begin{array}{l}\text { Danusia, Redstar, Triada, } \\
\text { Victoria, Zebra, Zeus }\end{array}$ & $\begin{array}{l}\text { Asterix, Bartek, } \\
\text { Mors, Triada, Zebra, }\end{array}$ & Bryza \\
\hline $\begin{array}{l}\text { poor, }>5- \\
6\end{array}$ & $\begin{array}{l}\text { Asterix, Beata, } \\
\text { Maryna, Redstar, } \\
\text { Tokaj }\end{array}$ & $\begin{array}{l}\text { Asterix, Beata, Maryna, } \\
\text { Mors, Tokaj, Wiking }\end{array}$ & $\begin{array}{l}\text { Bryza, Maryna, } \\
\text { Wiking, Victoria }\end{array}$ & $\begin{array}{l}\text { Bartek, Triada, Wiking, } \\
\text { Victoria, Zebra, Zeus }\end{array}$ \\
\hline bad, $4-5$ & Mors, Zeus & Bartek & $\begin{array}{l}\text { Beata, Danusia, } \\
\text { Redstar, Tokaj, Zeus }\end{array}$ & $\begin{array}{l}\text { Asterix, Danusia, Maryna, } \\
\text { Mors, Redstar, Tokaj }\end{array}$ \\
\hline
\end{tabular}

\subsection{Mineral Element Concentrations in Soil and Tubers}

Mineral element concentrations and $\mathrm{pH}$ values in soil samples collected in four locations are given in Table 3. In Table 4, coefficients of correlations between mineral elements content of tubers and soil samples are presented (concentration of $\mathrm{Ca}$ was only measured in tubers and values of $\mathrm{pH}-$ only in soil samples). The concentrations of elements in tubers were not or were only poorly correlated with their levels in soil, although some moderate values of correlation coefficients were obtained for $\mathrm{P}, \mathrm{Cu}, \mathrm{Fe}$ (negative values) and $\mathrm{Hg}$ (positive value). Similarly, the soil $\mathrm{pH}$ correlated poorly with $\mathrm{N}, \mathrm{K}, \mathrm{Mg}, \mathrm{Ca}, \mathrm{Mn}, \mathrm{Fe}$ and $\mathrm{Hg}$ content of tubers. The moderate correlations were found for $\mathrm{P}, \mathrm{Cu}$ (positive), $\mathrm{Pb}$ and $\mathrm{Zn}$ (negative). For $\mathrm{Cd}$ the correlation was high and negative.

Table 3. Mineral elements concentrations and $\mathrm{pH}$ measured in soil samples

\begin{tabular}{|c|c|c|c|c|c|c|c|c|c|c|c|c|}
\hline \multirow[b]{2}{*}{ Location } & $\mathrm{N}$ & $\mathrm{P}$ & $\mathrm{K}$ & $\mathrm{Mg}$ & $\mathrm{Pb}$ & $\mathrm{Cd}$ & $\mathrm{Cu}$ & $\mathrm{Zn}$ & $\mathrm{Hg}$ & $\mathrm{Mn}$ & $\mathrm{Fe}$ & \multirow{2}{*}{ soil $\mathrm{pH}$} \\
\hline & $\%$ & \multicolumn{3}{|c|}{ (mg $100 \mathrm{~g}^{-1}$ of soil) } & & \multicolumn{3}{|c|}{$\mathrm{mg} \mathrm{kg}^{-1}$ of dry soil } & & \multicolumn{2}{|c|}{$\mathrm{mg} \mathrm{kg}^{-1}$ of soil } & \\
\hline$\overline{\mathrm{O} 1}$ & 0.022 & 10.2 & 13 & 4.3 & 10.00 & 0.18 & 5.00 & 26.3 & 0.017 & 77.6 & 621 & 5.70 \\
\hline $\mathrm{O} 2$ & 0.025 & 20.8 & 22 & 3.1 & 9.00 & 0.16 & 3.87 & 22.6 & 0.017 & 139.2 & 730 & 7.18 \\
\hline $\mathrm{C} 1$ & 0.044 & 18.3 & 23 & 5.3 & 9.37 & 0.25 & 6.87 & 25.3 & 0.030 & 53.2 & 777 & 5.12 \\
\hline $\mathrm{C} 2$ & 0.023 & 14.9 & 8 & 4.4 & 7.50 & 0.10 & 5.00 & 21.7 & 0.021 & 130.2 & 678 & 4.06 \\
\hline
\end{tabular}


Table 4. Correlations between concentration of mineral elements in tubers and in soil or soil $\mathrm{pH}$

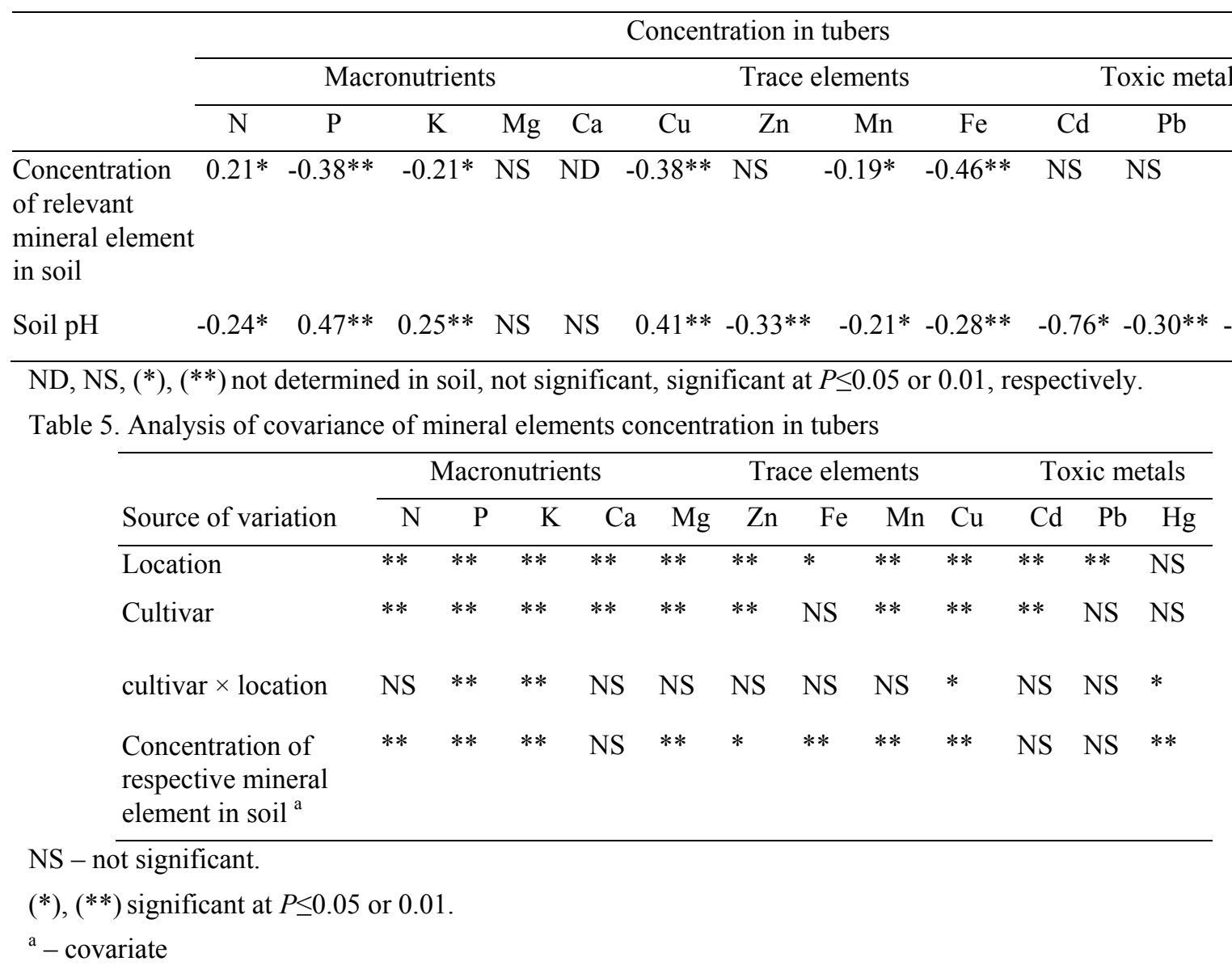

Statistical significance of effects influencing concentrations of elements in tubers are presented in Table 5 . Firstly, the effect of location is demonstrated, which was usually highly significant $(P \leq 0.01)$, with exceptions of $\mathrm{Fe}(P \leq 0.05)$ and $\mathrm{Hg}$ (not significant effect).

Secondly, effect of cultivar is presented. For most elements, this effect was highly significant $(P \leq 0.01)$ with exceptions of insignificant cultivar influence on tuber $\mathrm{Fe}, \mathrm{Pb}$, and $\mathrm{Hg}$ concentrations.

Thirdly, the influence of cultivar $\times$ location interaction was found to be statistically significant only for $\mathrm{P}, \mathrm{K}, \mathrm{Cu}$ and $\mathrm{Hg}$ content (Table 5).

The last evaluated effect was the soil concentration of elements, which was tested as covariate. The soil N, P, K, $\mathrm{Mg}, \mathrm{Fe}, \mathrm{Mn}, \mathrm{Cu}, \mathrm{Zn}$ and $\mathrm{Hg}$ concentrations affected their levels in tubers. For toxic metals $\mathrm{Cd}$ and $\mathrm{Pb}$, such effect was not observed. Ca level was measured only in tubers and values of soil $\mathrm{pH}$ were used as respective covariate. It turned out to have no effect on tuber Ca concentration (Table 5).

Mean concentration values for locations, together with results of multiple comparisons, are presented in Table 6 . The clear grouping for organic and conventional locations based on Tukey's HSD was only possible for concentrations of $\mathrm{P}, \mathrm{Cu}$ (clearly higher levels in organically grown tubers) and $\mathrm{Cd}$ (clearly higher in tubers from conventional locations).

More details on concentrations of mineral elements in tubers of examined cultivars are presented in Table 7. Apart from insignificant cultivar effect on tuber $\mathrm{Fe}, \mathrm{Pb}$ and $\mathrm{Hg}$ concentrations, relatively small variation was found among tested cultivars for concentrations of $\mathrm{P}$ and $\mathrm{Mn}$ (as indicated by comparisons of ranges of mean values with Tukey's HSD values). Moreover, in Table 7 cultivars are listed, for which the extreme concentrations of elements were found. There was a group of cultivars, which tend to accumulate some elements to a higher level in tubers as compared with others, namely cv. Tokaj (with the highest level of $\mathrm{P}, \mathrm{Mg}$, $\mathrm{Mn}$ and $\mathrm{Cu}$ ), cv. Redstar (the highest concentration of $\mathrm{N}$ and $\mathrm{Zn}$ ) and cv. Beata (the highest concentration of $\mathrm{K}$ and $\mathrm{Cd}$ ). The opposite tendency toward the lowest concentrations was observed for $\mathrm{cv}$. Zebra (for $\mathrm{P}, \mathrm{K}, \mathrm{Mg}, \mathrm{Mn}$ and $\mathrm{Cu}$ ), cv. Zeus (for P and K), cv. Maryna (for P, Mg, Mn and Zn), cv. Danusia (for P, Mn and Cd) or cv. 
Asterix (for $\mathrm{P}, \mathrm{Mn}, \mathrm{Cu}$ ) (Table 7).

Table 6. Mean values of mineral elements concentrations in tubers grown in organic $(\mathrm{O} 1, \mathrm{O} 2)$ and conventional $(\mathrm{C} 1, \mathrm{C} 2)$ locations

\begin{tabular}{|c|c|c|c|c|c|c|c|c|c|c|c|}
\hline \multirow[b]{2}{*}{ Location } & \multicolumn{5}{|c|}{ Macronutrients (\% of DM) } & \multicolumn{4}{|c|}{ Trace elements ( $\mathrm{mg} \mathrm{kg}^{-1}$ of DM) } & \multicolumn{2}{|c|}{$\begin{array}{c}\text { Toxic metals } \\
\left(\mathrm{mg} \mathrm{kg}^{-1} \text { of } \mathrm{DM}\right)\end{array}$} \\
\hline & $\mathrm{N}$ & $P$ & $\mathrm{~K}$ & $\mathrm{Ca}$ & $\mathrm{Mg}$ & $\mathrm{Zn}$ & $\mathrm{Fe}$ & $\mathrm{Mn}$ & $\mathrm{Cu}$ & $\mathrm{Cd}$ & $\mathrm{Hg}$ \\
\hline $\mathrm{O} 1$ & $1.04 \mathrm{bc}$ & $0.29 \mathrm{a}$ & $2.21 \mathrm{~b}$ & $0.03 \mathrm{a}$ & $0.13 \mathrm{a}$ & $12.76 \mathrm{a}$ & $60.87 \mathrm{a}$ & $7.56 \mathrm{~b}$ & $5.55 \mathrm{a}$ & $0.06 \mathrm{~b} 0.15 \mathrm{a}$ & $0.000075 \mathrm{a}$ \\
\hline $\mathrm{O} 2$ & $0.99 \mathrm{~b}$ & $0.25 \mathrm{~b}$ & $2.35 \mathrm{a}$ & $0.03 \mathrm{a}$ & $0.11 \mathrm{c}$ & $10.92 \mathrm{~b}$ & $46.84 \mathrm{~b}$ & $7.39 \mathrm{~b}$ & $3.90 \mathrm{~b}$ & $0.04 \mathrm{c} 0.12 \mathrm{~b}$ & $0.000057 \mathrm{a}$ \\
\hline $\mathrm{C} 1$ & $1.14 \mathrm{a}$ & $0.21 \mathrm{c}$ & $1.99 \mathrm{c}$ & $0.02 \mathrm{~b}$ & $0.12 \mathrm{~b}$ & $12.60 \mathrm{a}$ & $47.20 \mathrm{~b}$ & $9.29 \mathrm{a}$ & $2.76 \mathrm{c}$ & $0.11 \mathrm{a} 0.13 \mathrm{~b}$ & $0.000400 \mathrm{a}$ \\
\hline $\mathrm{C} 2$ & $1.09 \mathrm{ab}$ & $0.20 \mathrm{c}$ & $2.27 \mathrm{~b}$ & $0.04 \mathrm{a}$ & $0.12 \mathrm{~b}$ & $12.82 \mathrm{a}$ & $60.30 \mathrm{a}$ & $8.39 \mathrm{ab}$ & $2.85 \mathrm{c}$ & 0.13 a $0.15 \mathrm{a}$ & $0.000186 \mathrm{a}$ \\
\hline
\end{tabular}

Mean values followed by the same letter for each column do not differ significantly at $P \leq 0.05$.

Table 7. Concentration of mineral elements in tubers of examined cultivars

\begin{tabular}{|c|c|c|c|c|c|c|}
\hline \multirow{2}{*}{\multicolumn{2}{|c|}{ Elements in tubers ${ }^{a}$}} & \multicolumn{2}{|c|}{$\begin{array}{l}\text { Concentration in } \\
\text { tubers }\end{array}$} & \multirow{2}{*}{$\begin{array}{l}\text { Tukey's } \\
\text { HSD }\end{array}$} & \multicolumn{2}{|c|}{ Cultivars with mineral elements concentration } \\
\hline & & $\min$ & $\max$ & & the lowest & the highest \\
\hline \multirow[t]{5}{*}{ Macronutrients } & $\mathrm{N}$ & 0.84 & 1.35 & 0.24 & Beata & Redstar \\
\hline & $\mathrm{P}$ & 0.21 & 0.27 & 0.04 & $\begin{array}{l}\text { Asterix, Bryza, Danusia, Maryna, } \\
\text { Zebra, Zeus }\end{array}$ & Tokaj \\
\hline & $\mathrm{K}$ & 2.06 & 2.40 & 0.21 & Zebra, Zeus & Beata \\
\hline & $\mathrm{Ca}$ & 0.02 & 0.04 & 0.01 & Triada & Mors \\
\hline & $\mathrm{Mg}$ & 0.10 & 0.14 & 0.02 & Maryna & Tokaj \\
\hline \multirow[t]{3}{*}{ Trace elements } & $\mathrm{Zn}$ & 10.24 & 15.76 & 2.15 & Maryna & Redstar \\
\hline & $\mathrm{Mn}$ & 6.64 & 10.80 & 3.51 & $\begin{array}{l}\text { Asterix, Danusia, Maryna, Wiking, } \\
\text { Zebra }\end{array}$ & Tokaj \\
\hline & $\mathrm{Cu}$ & 3.03 & 5.51 & 0.94 & Asterix, Zebra & Tokaj \\
\hline Toxic metal & $\mathrm{Cd}$ & 0.06 & 0.11 & 0.03 & Danusia & Beata \\
\hline
\end{tabular}

Statistically significant correlations between agronomic traits evaluated for the 14 cultivars and levels of mineral elements are presented in Table 8. The majority of coefficients were low and statistically insignificant. Concentrations of macronutrients (N, P, K) correlated usually moderately and negatively with some agronomic traits, like content of starch, flavor of tubers, total and marketable tuber yield and tuber size. The exception was a very high and negative correlation between tuber $\mathrm{P}$ and total tuber yield.

Table 8. Correlations between agricultural traits and tuber elements concentrations

\begin{tabular}{|c|c|c|c|c|c|c|c|c|}
\hline \multirow[b]{2}{*}{ Trait } & \multicolumn{8}{|c|}{ Mineral element in tuber } \\
\hline & $\mathrm{N}$ & $\mathrm{P}$ & $\mathrm{K}$ & $\mathrm{Cu}$ & $\mathrm{Zn}$ & $\mathrm{Mn}$ & $\mathrm{Cd}$ & $\mathrm{Hg}$ \\
\hline Total tuber yield & & $-0.72 * *$ & $-0.36^{* *}$ & $-0.69 * *$ & & & $0.81 * *$ & $0.36^{* *}$ \\
\hline Fraction of marketable tuber yield & & $-0.47 * *$ & & $-0.46^{* *}$ & & & $0.35^{*}$ & \\
\hline Tuber size & & $-0.37 * *$ & & & & & $0.31^{*}$ & \\
\hline Starch content & $-0.30^{*}$ & & & & $-0.42 * *$ & & & \\
\hline Tuber shape & & & & & & & & $-0.28 *$ \\
\hline Regularity of tuber shape & & & & & & $-0.51^{* *}$ & $-0.36^{* *}$ & $-0.34 *$ \\
\hline Depth of eyes & & & & & & $-0.50 * *$ & $-0.33^{*}$ & $-0.36^{* *}$ \\
\hline Flavour of tubers & $-0.32 *$ & & & & $-0.35^{* *}$ & $-0.45^{* *}$ & $-0.30 *$ & $-0.35 * *$ \\
\hline
\end{tabular}

Insignificant or very low coefficients were omitted.

Tuber trace elements concentrations correlated negatively with total and marketable yields, starch content, tuber flavor and tuber morphology.

In the case of toxic metals, some positive correlations were found as for tuber yield or marketable yield and 
concentrations of $\mathrm{Cd}$ and $\mathrm{Hg}$. The concentrations of $\mathrm{Cd}$ or $\mathrm{Hg}$ in tubers were also correlated moderately and negatively with tuber morphology and tuber flavor. The higher levels of $\mathrm{Hg}$ were related with decreased scores for tuber shape (i.e. more rounded tubers).

Values of measured variables (agronomical traits and concentration of elements) were subjected to PCA. The first two components accounted for $43.6 \%$ of the total variance and first five components accounted for $73.3 \%$ of this variance. Scores for each observation for the first two components are presented in Figure 1 as a clearly separated two sets of points corresponding to organic and conventional system of cultivation.

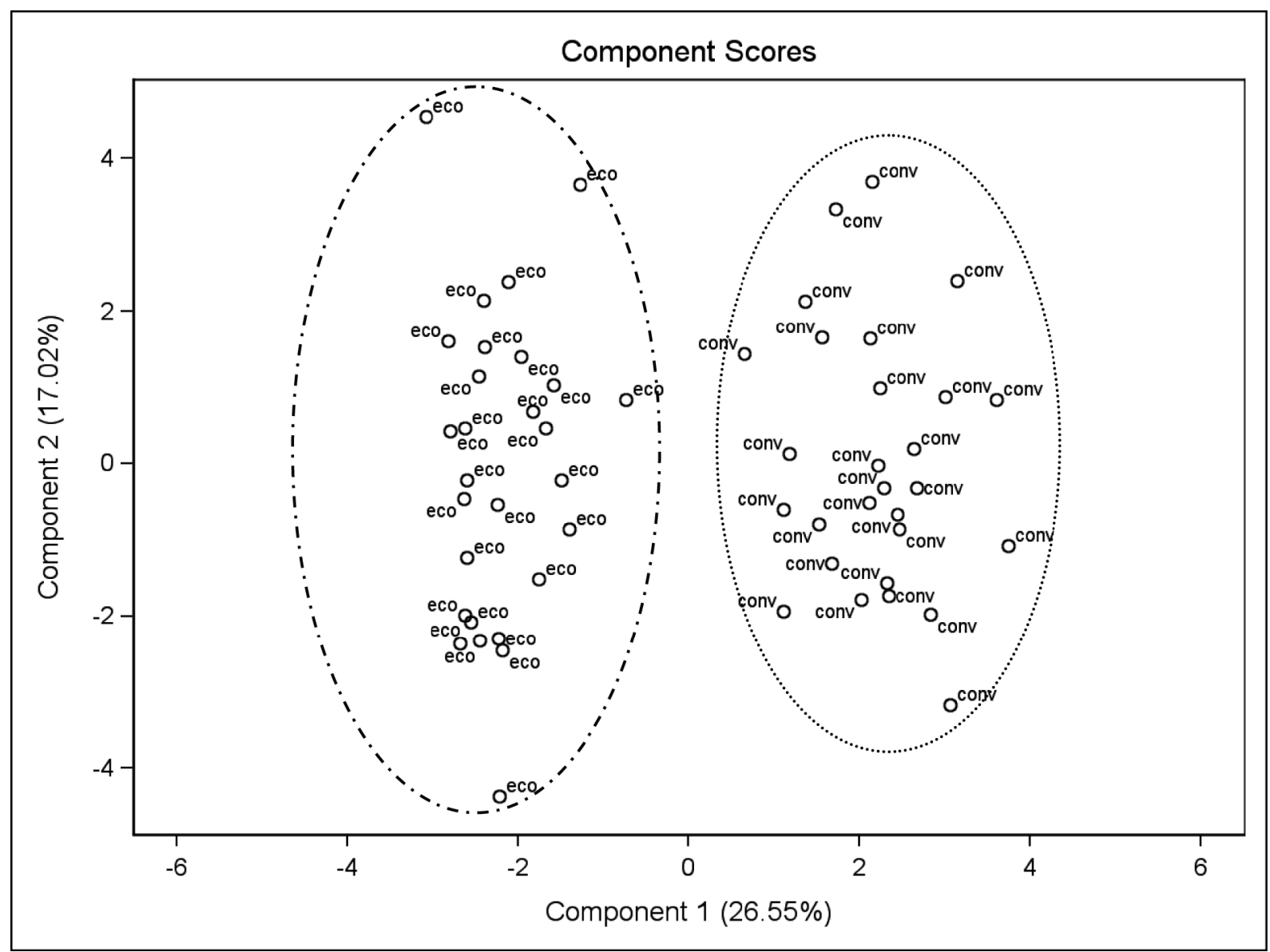

Figure 1. Biplot of first (Component 1) and second principal component (Component 2) for data from four locations (eco - for organic and conv - for conventional system) and 14 cultivars. The data included concentrations of 12 elements in tubers, tuber yield, tuber taste and their morphological characteristics

The variable was considered to load on a given component, if the factor loading was greater than 0.3 for that component (data not shown). According to this criterion, tuber yield and tuber $\mathrm{Cd}, \mathrm{P}, \mathrm{Cu}$ concentrations were found to load on the first component. The first component may be called "conventional system characteristic", since it indicates that high tuber yield is related to a high concentration of $\mathrm{Cd}$ and low (or lowered) concentrations of $\mathrm{P}$ and $\mathrm{Cu}$.

The second component was built by positive loadings of tuber of $\mathrm{N}, \mathrm{Mg}$ and $\mathrm{Zn}$ concentrations. The tuber size and tuber shape loaded on the third, regularity of tuber shape, depth of eyes and tuber $\mathrm{N}, \mathrm{Fe}, \mathrm{Pb}$ concentrations on the fourth and tuber size, tuber shape and Ca concentration - on the fifth component.

\section{Discussion}

\subsection{Tuber Flavor and Other Agronomical Traits}

Presented flavor evaluations allow drawing two conclusions. Firstly, the evaluating panel was able to discriminate between tubers from organic and conventional fields, i.e. tubers samples from organic locations were scored significantly higher and such samples were much more frequent. This is in accordance with studies of Rembiałkowska (2003), Wszelaki et al. (2005) and Varis et al. (1996), although other authors reported lack of 
clear differences between flavors of organically and conventionally grown tubers (e.g. Hajšlova et al., 2005). Secondly, due to significant cultivar $\times$ location interaction, assessments for specific cultivar from different locations varied, in some cases largely. However, a group of seven cultivars reacted positively to the organic cultivation, while a few ones received only one higher rating of flavor for tubers grown conventionally. The flavor correlated poorly or moderately and only negatively with concentration of some elements (discussed further in the paper).

As for general performance of potato cultivars, some important differences between organic and conventional locations were observed. Namely, tuber yield from organic fields was significantly lower as compared with yield from conventional locations. Such limitation for organic system is often reported as the result of lowered fertilizers input (Varis et al., 1996; Hajšlova et al., 2005; Maggio et al., 2008). However, Warman and Havard (1998) reported lack of differences between tuber yields from conventional and organic systems, while Schuphan (1974) found that tuber yield depends on type of fertilizer (the lowest yield if manure was applied, but the highest after using biodynamical compost) and soil. In the present study, marketable yield was also lowered in organic locations, but the size of tubers was not reduced in the same way, probably as a result of parallel change in tuber shape. This may be illustrated by the relatively high marketable yield in $\mathrm{C} 1$, but tubers size the same as in $\mathrm{O} 1$, where marketable yield was the lowest due to significantly elongated tubers. Organically grown tubers had the significantly better morphology, which may have positive impact on reception of organic potatoes by customers.

The starch content did not clearly depend on cultivation system. In other studies, the dry matter content, closely associated with the percentage of starch, increased along with increasing fertilization with inorganic N (Müller \& Hippe, 1987) or was higher in organic potatoes (Rembiałkowska, 2003; Hajšlova et al., 2005; Kolbe et al., 1995) or differences between both systems in this respect were not found (Maggio et al., 2008). Schuphan (1974) in his long-term experiments found a small decrease of dry matter in potatoes fertilized with manure or biodynamic compost.

\subsection{Macronutrients and Trace Elements in Tubers}

In the present study, tuber concentrations of mineral elements depended on the effect of location and cultivar (with exception of $\mathrm{Fe}$ concentration). The interactions of both these factors were significant in the cases of tuber $\mathrm{P}, \mathrm{K}$ and $\mathrm{Cu}$ concentrations. The organically grown tubers had lower tuber $\mathrm{N}$ and $\mathrm{Mn}$ concentrations, but clear differences between organic and conventional systems were not found. Tuber $\mathrm{P}$ and $\mathrm{Cu}$ concentrations were clearly higher in organically grown tubers than in tubers from conventional locations. For tuber $\mathrm{K}, \mathrm{Ca}, \mathrm{Mg}, \mathrm{Fe}$ and $\mathrm{Zn}$ concentrations differences between cultivation systems were not so evident.

It is accepted that application of mineral fertilizers leads to increase of tuber concentration of supplied minerals (reviewed by White et al., 2009). Usually, the concern is tuber $\mathrm{N}$ concentration, since this element is present either in valuable compounds (e.g. in tuber proteins) or in compounds, which might be harmful for human (e.g. nitrates). Mineral N fertilizers increase tuber N and/or nitrates concentrations (Rembiałkowska, 1999; Vogtmann et al., 2009). However, in study of Müller and Hippe (1987) such an increase was also found for organic forms of nitrogen. The decreased ( $\mathrm{N}$ and $\mathrm{Mn}$ ) or increased ( $\mathrm{P}, \mathrm{K}, \mathrm{Ca}, \mathrm{Mg}$ and $\mathrm{Fe}$ ) concentrations of mineral elements in organically grown tubers were also found by others (Schupan 1974; Warman \& Havard, 1998; Wszelaki et al., 2005). In present study, some of these effects may be explained by the soil acidity. Namely, in both conventional locations, soil had much lower $\mathrm{pH}$, what created favourable conditions for increased tuber $\mathrm{Mn}$ and decreased tuber P concentrations (Marschner, 1991). Obviously, the soil $\mathrm{pH}$ is not related to cultivation system.

Furthermore, it was shown with few exceptions that minerals concentration in tubers depended on their soil concentration. This may also indicate that the effect of location is more important than the effect of cultivation system. As indicated by Rivero et al. (2003) and Di Giacomo et al. (2007), the effect of "location" might be so strong that the assessment of the mineral elements in potato tubers can be used to verify the growing region. However, correlations between soil and tuber concentrations were insignificant or at most moderate and negative (with the exception of positive correlation of $\mathrm{N}$ concentrations). This may point to complex relationships between soil and plant (White et al., 2009).

Beside effect of location, the cultivar was the factor, which significantly influenced concentration of tested minerals (with exception of $\mathrm{Fe}$ ). Some cultivars tended to accumulate minerals to higher or lower concentrations. Rivero et al. (2003) and Di Giacomo et al. (2007) demonstrated a similar diversity of potato cultivars in the concentration of minerals in tubers. White et al. (2009) suggested that breeding for increased yield and increased concentrations of some minerals $(\mathrm{P}$ and $\mathrm{Cu})$ is feasible. 


\subsection{Toxic Metals in Tubers}

The concentrations of three toxic metals in tubers were examined and found to be affected by location $(\mathrm{Pb})$, location and cultivar $(\mathrm{Cd})$ or, as in the case of $\mathrm{Hg}$, by cultivar $\times$ location interaction and the soil concentration. The highest concentrations of $\mathrm{Cd}$ and $\mathrm{Hg}$ were found in tubers from conventional locations. All these metals occur in soil minerals and enter agricultural soils in different ways, e.g. phosphate fertilizers are believed to be main source of Cd (McLaughlin et al., 1999). The latter might be assumed as the reason of observed high concentration of $\mathrm{Cd}$ in conventionally grown tubers, which was not affected by its soil concentration. The uptake of Cd by plants is especially widely discussed, since this metal is extremely mobile carcinogen (Magkos et al., 2006). Many factors influence the uptake of toxic metals and concentration in edible parts of plants. Among soil factors, a primary is a low $\mathrm{pH}$, which is especially important in the case of $\mathrm{Cd}$ (McLaughlin et al., 1999). The amount of $\mathrm{Cd}$, which is accumulated and translocated in plants, varies with species and cultivars (Grant et al., 1998; McLaughlin et al., 1994). The cultivation system need not be solely responsible for Cd content of plants (Jorhem \& Slanina, 2000). This seems also to be quite clear in the cases of $\mathrm{Pb}$ or $\mathrm{Hg}$ content in tubers, for which the only significant effects were those associated with the location or interaction cultivar $\times$ location and their concentrations in soil.

\subsection{Relationship between Mineral Elements Concentrations in Tubers and Agronomic Traits}

The correlations between concentration of macro/trace elements and agronomical traits were rare, mostly negative and moderate. Such correlations were observed between concentrations of N, $\mathrm{Zn}$ or $\mathrm{Mn}$ and flavour or between $\mathrm{N}$ or $\mathrm{Zn}$ and starch content. There is commonly held perception that tuber flavour decreases with elevated doses of nitrogen fertilizers. According to Jansky (2010), this flavour decline may be caused by an increased production of acrid tasting nitrogen compounds like amides and amines. On the other hand, the lowered $\mathrm{Zn}$ accumulation in tasty tubers might be a problem for organic potato growers, since tubers are believed to be a quite significant source of this element (Navarre et al., 2009).

A few correlations indicated stronger relationship as in the case of high and negative correlations between tuber yield and concentration of $\mathrm{P}$ or $\mathrm{Cu}$. In the case of $\mathrm{P}$, higher accumulation of $\mathrm{P}$ was found in tubers from "lower yielding" plots. Such plots usually were those from organic locations, where the soil had higher $\mathrm{pH}$ values than in conventional locations. In soils with low $\mathrm{pH}$, solubility of phosphorus compounds is decreased, which eventually lead to $\mathrm{P}$ deficiency in plants (Marschner, 1991). The highly negative correlation between $\mathrm{Cu}$ concentration and tuber yield may be due to applying copper fungicides in organic locations, in which level of $\mathrm{Cu}$ in soil was the same or lower than in soil from conventional locations. In turn, the explanation of at least moderate and negative correlations between tuber Mn concentration and tuber morphology or flavour, might be low $\mathrm{pH}$ of the soil, what is related with higher accumulation of $\mathrm{Mn}$ in plants (Marschner, 1991). Such values were observed in soil samples from conventional locations. Tubers from these locations had significantly lowered scores for regularity of tuber shape, depth of eyes and flavour. It must be added, that negative correlation between soil $\mathrm{pH}$ and concentration of $\mathrm{Mn}$ in tubers was poor.

In the case of toxic metals $\mathrm{Cd}$ and $\mathrm{Hg}$, the positive correlations with tuber yield occurred and some were high, like between $\mathrm{Cd}$ in tubers and tuber yield. This might be connected with high doses of phosphorus fertilizers (source of $\mathrm{Cd}$ ) and/or low soil $\mathrm{pH}$ in conventional locations. Furthermore, concentrations of $\mathrm{Cd}$ and $\mathrm{Hg}$ were correlated moderately and negatively with quality traits, including flavour. The compounds of these metals might be responsible for worst flavour. Other possible explanation is that tubers with worst flavour come from locations that favour elevated concentration of toxic metals in tubers.

PC analysis indicates the clear separation of the two systems (Figure 1) due to differences in tuber yield and concentrations of $\mathrm{N}, \mathrm{P}, \mathrm{Mg}, \mathrm{Cu}, \mathrm{Zn}$ and $\mathrm{Cd}$, as indicated by loadings of first and second principal components. However, in some cases, the differences in these concentrations are the result of local influence of factors beyond the cultivation system (e.g. soil $\mathrm{pH}$ ).

\section{Conclusions}

Organically grown potatoes had lowered tuber yield but substantially elevated characteristic of tuber quality traits, i.e. flavors and morphology. Since the cultivar by location interaction affected levels of quality traits, it seems reasonable to conclude that organic farming increases the chances for such improvement, but only for potato cultivar(s) adapted to specific growing conditions.

Potato is relatively important source of some minerals ( $\mathrm{K}, \mathrm{P}, \mathrm{Mg}$ and Fe, $\mathrm{Zn}$ ). The study has shown that organic cultivation may increase tuber $\mathrm{P}$ concentration, but for $\mathrm{K}, \mathrm{Mg}, \mathrm{Fe}, \mathrm{Zn}$ the effect of cultivation system was less pronounced than the effect of location. The effect of location is visible in the case of toxic metals, which content 
in tubers depended on interaction cultivar $\times$ location and their concentrations in soil or soil $\mathrm{pH}$. The mineral composition of tubers reflects local variation in this respect rather than differences between organic and conventional cultivation systems.

The groups of cultivars can be distinguished, which tend to accumulate some elements to higher or lower level as compared with others. This ability might be a cultivar characteristic, since for most tested elements cultivar $\times$ location interactions were not significant. It indicates that breeding methods might be applied to create potatoes cultivars, which are able to accumulate some minerals to desired levels.

\section{References}

Bourn, D., \& Prescott, J. (2002). A Comparison of the nutritional value, sensory qualities, and food safety of organically and conventionally produced foods. Critical Review of Food Science and Nutrition, 42(1), 1-34. http://dx.doi.org/10.1080/10408690290825439

Di Giacomo, F., Del Signore, A., \& Giaccio, M. (2007). Determining the geographic origin of potatoes using mineral and trace element content. Journal of Agricultural and Food Chemistry, 55(3), 860-866. http://dx.doi.org/10.1021/jf062690h

Domański, L. (2001). Assessment of morphological characters of potato tubers. Monografie i Rozprawy Naukowe IHAR Nr 10a, 92-95.

Domański, L. (2001a). Assessment of cooking quality of potatoes. Monografie i Rozprawy Naukowe IHAR Nr $10 a, 96-100$.

Grant, C. A., Buckley, W. T., Bailey, L. D., \& Selles, F. (1998). Cadmium accumulation in crops. Canadian Journal of Plant Science, 78, 1-17. http://dx.doi.org/10.4141/P96-100

Hajšlova, J., Schulzová, V., Slanina, P., Janné, K., Hellenäs, K. E., \& Andersson, Ch. (2005). Quality of organically and conventionally grown potatoes: four-year study of micronutrients, metals, secondary metabolites, enzymic browning and organoleptic properties. Food Additives \& Contaminants, 22(6), 514-534. http://dx.doi.org/10.1080/02652030500137827

Jansky, S. H. (2010). Potato flavour. American Journal of Potato Research, 87, 209-217. http://dx.doi.org/10.1007/s12230-010-9127-6

Jorhem, L., \& Slanina, P. (2000). Does organic farming reduce the content of Cd and certain other trace metals in plant foods? A pilot study. Journal of the Science of Food and Agriculture, 80, 43-48. http://dx.doi.org/10.1002/(SICI)1097-0010(20000101)80:1<43::AID-JSFA482>3.0.CO;2-Y

Kamasa, J., \& Lenartowicz, T. (2005), Potato, in Descriptive list of Agricultural Plant Varieties, part 2, COBORU Słupia Wielka, 15-44.

Kärenlampi, S. O., \& White, P. J. (2009). Potato proteins, lipids and minerals. In J. Singh \& L. Kaur (Eds.) Advances in potato chemistry and technology, (pp. 99-125) Elsevier. http://dx.doi.org/10.1016/B978-0-12-374349-7.00005-2

Kolbe, H., Meineke. S., \& Zhang, W. L. (1995). Differences in organic and mineral fertilization on potato tuber yield and chemical composition compared to model calculations. Agribiological Research, 48(1), 63-73.

Lairon, D. (2009). Nutritional quality and safety of organic food. A review. Agronomy for Sustainable Development, 30(1), 33-42. http://dx.doi.org/10.1051/agro/2009019

Lisińska, G., \& Leszczyński, W. (1989). Potato science and technology. Elsevier Applied Science. London.

Maggio, A., Carillo, P., Bulmetti, G. S., Fuggi, A., Barbieri, G., \& De Pascale, S. (2008). Potato yield and metabolic profiling under conventional and organic farming. European Journal of Agronomy, 28, 343-350. http://dx.doi.org/10.1016/j.eja.2007.10.003

Magkos, F., Arvaniti, F., \& Zampelas, A. (2006). Organic food: Buying more safety or just peace of mind? A critical review of the literature. Critical Review of Food Science and Nutrition, 46, 23-56. http://dx.doi.org/10.1080/10408690490911846

Marschner, H. (1991). Mechanisms of adaptation of plants to acid soils. Plant and Soil, 134, 1-20.

McLaughlin, M. J., Palmer, L. T., Tiller, K. G., Beech, T. A., \& Smart, M. K. (1994). Increased soil salinity causes elevated cadmium concentrations in field-grown potato tubers. Journal of Environmental Quality, 23, 1013-1018. http://dx.doi.org/10.2134/jeq1994.00472425002300050023x

McLaughlin, M. J., Parker, D. R., \& Clarke, J. M. (1999). Metals and micronutrients - food safety issues. Field 
Crop Research, 60, 143-163. http://dx.doi.org/10.1016/S0378-4290(98)00137-3

Müller, K., \& Hippe, J. (1987). Influence of differences in nutrition on important quality characteristics of some agricultural crops. Plant and Soil, 100, 35-45. http://dx.doi.org/10.1007/BF02370931

Navarre, D. A., Goyer, A., \& Shakya, R. (2009). Nutritional value of potatoes; vitamin, phytonutrient and mineral content. In J. Singh \& L. Kaur (Eds.) Advances in potato chemistry and technology, (pp. 395-424) Elsevier. http://dx.doi.org/10.1016/B978-0-12-374349-7.00014-3

Rembiałkowska, E. (1999). Comparison of the contents of nitrates, nitrites, lead, calcium, nitrates, nitrites, lead, calcium and vitamin $\mathrm{C}$ in potatoes from conventional and ecological farms. Polish Journal of Food and Nutrition Sciences, 8/49(4), 17-26.

Rembiałkowska, E. (2003). Organic Farming as a System to Provide Better Vegetable Quality. In Tijskens \& Vollebregt (Eds.): Proceedings of International Conference Quality in Chains, Acta Horticulturae, 604, 473-479.

Rivero, R. C., Hernandez, P. S., Rodriguez, E. M. R., Martin, J. D., \& Romero, C. D. (2003). Mineral concentrations in cultivars of potatoes. Food Chemistry, 83, 247-253. http://dx.doi.org/10.1016/S0308-8146(03)00087-6

Schuphan, W. (1974). Nutritional value of crops as influenced by organic and inorganic fertilizer treatments. Results of 12 years' experiments with vegetables (1960-1972). Qualitas Plantarum (Plant Foods for Human Nutrition), 23(4), 333-358. http://dx.doi.org/10.1007/BF01095422

Varis, E., Pietilä, L., \& Koikkalainen, K. (1996). Comparison of conventional, integrated and organic potato production in field experiments in Finland. Acta Agriculturae Scandinavica B, 46, 41-48. http://dx.doi.org/10.1080/09064719609410945

Vogtmann, H., Matthies, K., Kehres, B., \& Meier-Ploeger, A. (1993). Enhanced food quality: effects of composts on the quality of plant foods. Compost Science and Utilization, 1, 82-100.

Warman, P. R., \& Havard, K. A. (1998). Yield, vitamin and mineral contents of organically and conventionally grown potatoes and sweet corn. Agriculture, Ecosystems \& Environment, 68, 207-216. http://dx.doi.org/10.1016/S0167-8809(97)00102-3

White, P. J., Bradshaw, J. E., Dale, M. F. B., \& Ramsay, G. (2009). Relationship between yield and mineral concentrations in potato tubers. HortScience, 44(1), 6-11.

Wszelaki, A. L., Delwiche, J. F., Walker, S. D., Liggett, R. E., Scheerens, J. C., \& Kleinhenz, M. D. (2005). Sensory quality and mineral and glycoalkaloid concentrations in organically and conventionally grown redskin potatoes (Solanum tuberosum). Journal of the Science of Food and Agriculture, 85, 720-726. http://dx.doi.org/10.1002/jsfa.2051

Zgórska, K. (2001). Determination of starch in potato tubers. Monografie i Rozprawy Naukowe IHAR Nr 10a, 111-114. 